The Review of Finance and Banking

print ISSN 2067-2713, online ISSN 2067-3825

Volume 11, Issue 2, Year 2019

http://dx.doi.org/10.24818/rfb.19.11.02.01, Pages 43-57

\title{
COMPETITION AND STABILITY IN AFRICAN BANKING
}

\author{
SIMEON PAPADOPOULOS
}

\begin{abstract}
This paper investigates the implications of market power on issues of bank efficiency and stability in African developing countries. Using data from 229 banks in 7 African economies over the period 2009-2016, we calculate market power, bank efficiency and stability estimates at the bank level. We employed different specifications of the conventional Lerner indicator to measure the degree of market power and the Z-index to account for bank stability. Bank efficiency scores were estimated with the stochastic frontier analysis. Our results show that a higher degree of market power results in profit efficiency gains and enhanced bank stability, despite significant cost efficiency losses. Further, as banks gain market power, they also benefit from greater firm stability and reduced risk potential. This result supports the traditional view that increased competition may undermine bank stability. Our results also seem to suggest that efficiency Granger-causes market power indicating, that changes in profit efficiency precede changes in market power. Banks that are able to operate more profit efficiently will gain greater market power in comparison with their peers. Overall, our findings seem to suggest that higher degrees of market power bring about greater profit rates and enhanced bank stability.
\end{abstract}

\section{INTRODUCTION}

The arguments in favour of greater competition, in principle, apply to all industries and derive from applying classical industrial organization economics. Berger and Hannan (1998) argue that banks not exposed to competition tend to be less efficient than banks subject to more competition. When market power prevails, managers may pursue objectives other than profit maximization, and they do not have incentives to work hard to keep costs under control, thereby reducing cost efficiency. The authors find evidence that a "quiet life" effect prevails in US banking suggesting that banks not exposed to competition tend to be less efficient than banks subject to more competition.

Compared to the voluminous body of literature on bank efficiency, research on the relationship between market structure and bank efficiency is limited for developed markets and practically non-existent for developing countries. Casu and Girardone (2006) derive bank efficiency estimates using the non-parametric Data Envelopment Analysis methodology and include it as an exogenous variable in estimating the PR H-statistic. Using a sample of banks in the European Union, they do not find a clear relationship between efficiency and competition. However, the PR H-statistic which is calculated from reduced form bank revenue equations and measures the sum of the elasticity of bank interest revenues with respect to banks' input prices, is contested as a continuous and long-run measure of competition (Shaffer, 2004). It is also calculated at the national level and cannot be used to assess firm-level decisions of banks. Three studies use the Lerner index or a bank-level measure of competition to investigate the implications of market power on bank efficiency in the context of developed countries. Maudos

Received by the editors May 31, 2019. Accepted by the editors July 18, 2019.

Keywords: African banking; efficiency; market power; Lerner index.

JEL Classification: G21, G15, D4.

Simeon Papadopoulos, PhD, Department of Accounting and Finance, University of Macedonia, Thessaloniki, Greece. E-mail: spapado@uom.gr.

This paper is in final form and no version of it will be submitted for publication elsewhere. 
and De Guevara (2007) find a positive relationship between market power and cost efficiency in European banking, thus rejecting the "quiet life" hypothesis. However, a comprehensive analysis of the relationship between market power and efficiency should consider both cost and profit efficiency. While cost minimization is a necessary condition to maximize profits, banks may also achieve higher profits by diversifying their revenue sources. Using US and European samples, Schaeck and Cihak (2008) report that competition improves profit efficiency.

This paper investigates the implications of market power on issues of bank efficiency and stability in African developing countries where capital markets are relatively underdeveloped, and banks represent the main providers of credit to the economy. Developing countries provide a fertile laboratory to examine issues of competition because they are engaged in a process of deregulation, bank privatization and financial liberalization, while the industry is witnessing more consolidation. Changing banking structures, in turn, raises concerns about competitive conditions, the efficiency in the delivery of financial services, and overall bank stability. These issues are of particular importance in light of the adverse implications of the recent financial crisis for developing countries (International Monetary Fund, 2009).

Related research which examines simultaneously the inter-relatedness between bank competition, efficiency, and stability is by Schaeck and Cihak (2008) on European and placecountryregionUS banking. The authors use a traditional Lerner index to establish that competition increases bank efficiency. They also estimate the Boone indicator (a country-level measure of the intensity of competition based on the idea that more efficient firms will gain market share in a competitive environment) to show that competition increases bank soundness.

This study differs from previous work in terms of sample coverage and methodology. First, no prior research has to our knowledge addressed the complex interaction between competition, efficiency and stability in the context of developing countries. Second, we investigate the interrelatedness between key variables of interest - market power, efficiency and stability - at the bank level to lend more support to the analysis. Specifically, the Lerner index is a banklevel measure of the degree of competition, which is preferred over nation-wide proxies such as traditional concentration ratios or the Panzar and Rosse (PR, 1987) H-statistic.

Third, since no consensus prevails in the literature regarding how best to assess the degree of market power in banking (Carbó et al., 2009), we consider two different specifications of the Lerner index. In addition to the traditional price mark-up over marginal cost estimation (Berger et al., 2009), we employ a structural model to derive one more adjusted Lerner index: an efficiency-adjusted Lerner (Maudos and De Guevara, 2007, Koetter et al., 2008). The intuition is that both bank stability and efficiency may affect the degree of market power, resulting in an endogeneity bias in the traditional Lerner estimation. Thus, the two different Lerner specifications are likely to provide more robustness to the analysis. In addition, we run a series of Granger causality tests in an attempt to analyze the nexus between two measures of profit efficiency (standard profit efficiency and alternative profit efficiency) and the Lerner index.

\section{LITERATURE REVIEW}

The arguments in favor of greater competition, in principle, apply to all industries and derive from applying classical industrial organization economics. Berger and Hannan (1998) argue that banks not exposed to competition tend to be less efficient than banks subject to more competition. When market power prevails, managers may pursue objectives other than profit maximization, and they do not have incentives to work hard to keep costs under control, thereby reducing cost efficiency. The authors find evidence that a "quiet life" effect prevails in US banking.

Compared to the voluminous body of literature on bank efficiency, research on the relationship between market structure and bank efficiency is limited for developed markets and practically non-existent for developing countries. Casu and Girardone (2006) derive bank efficiency estimates using the non-parametric Data Envelopment Analysis methodology and include it as 
an exogenous variable in estimating the PR H-statistic. Using a sample of banks in the European Union, they do not find a clear relationship between efficiency and competition. However, the PR H-statistic is contested as a continuous and long-run measure of competition (Shaffer, 2004). It is also calculated at the national level and cannot be used to assess firm-level decisions of banks.

Three studies use the Lerner index or a bank-level measure of competition to investigate the implications of market power on bank efficiency in the context of developed countries. Maudos and De Guevara (2007) find a positive relationship between market power and cost efficiency in European banking, thus rejecting the "quiet life" hypothesis. However, a comprehensive analysis of the relationship between market power and efficiency should consider both cost and profit efficiency. While cost minimization is a necessary condition to maximize profits, banks may also achieve higher profits by diversifying their revenue sources.

More recently, Delis and Tsionas (2009) provide an empirical framework for the joint estimation of efficiency and market power for a sample of European and US banks. The authors use a novel maximum localization technique to derive bank-specific estimates of market power, and report a negative relationship between market power and efficiency, in line with the predictions of the "quiet life" hypothesis.

2.1. Market power and bank stability. The traditional "competition-fragility" view contends that market power in banking may be desirable, despite possible ensuing efficiency losses. A bank with market power is likely to reduce the information asymmetry problem and develop on-going relationships with individual firms (Petersen and Rajan, 1995). Incumbent banks are prone to screen borrowers and differentiate between low- and high-quality debtors (Cetorelli and Peretto, 2000). This may improve loan portfolio quality and enhance bank stability. Besanko and Thakor (1993) find that banks which appropriate informational rents from developing relationships with borrowers may have more incentives to limit their risk exposure. Keeley (1990) finds that increased competition has eroded the franchise value of placecountry-regionUS banks, leading to more risk-taking and a surge of bank failures in the 1980s. Carletti and Vives (2008) review the literature on competition and stability and show that, while banking is no longer an exception in the enforcement of competition policy rules in the European Union, market power may have a moderating effect on bank risk-taking incentives.

Recently, a counter trend has emerged both at the theoretical and empirical levels to support the "competition-stability" view and refute the traditional trade-off between market power and bank stability. Caminal and Matutes (2002) show that monopoly banks incur monitoring costs and are inclined to originate risky loan portfolios; Beck et al. (2004) report that bank stability is enhanced in both more concentrated and competitive markets; and Allen and Gale (2004) argue that this relationship is complex and case dependent. Boyd and De Nicoló (2005) argue that the implications of market power have to be examined separately for the deposit and loan markets. Banks with more loan market power are in a position to charge higher rates to their customers. This makes it harder for borrowers to repay loans, thereby exacerbating moral hazard incentives to shift into riskier projects and possibly resulting in a riskier set of bank clients due to adverse selection considerations.

A large body of empirical evidence employs concentration ratios to support the "competitionstability" view (see for example De Nicoló, 2000; De Nicoló et al., 2004; Boyd et al., 2006; Uhde and Heimeshoff, 2009). Alternatively, Schaeck et al. (2009) use the PR H-statistic to show that competitive banking markets are more stable than monopolistic systems. Schaeck and Cihak (2008) employ another country-level measure of the intensity of competition (the Boone indicator) to establish that competition increases bank soundness through the efficiency channel. 


\section{METHODOLOGY}

This paper employs two different specifications of Lerner to investigate the implications of market power: a conventional Lerner (Berger et al., 2009) and an efficiency-adjusted Lerner (Koetter et al., 2008).

The conventional Lerner indicator of market power is defined as:

$$
\left(P_{T A}-M C_{T A}\right) / P_{T A}
$$

The Lerner index captures the essence of pricing power because it measures the disparity between price and marginal costs expressed as a percentage of price. Ideally, output price or $P_{T A}$ should take into consideration the price of loans and deposits separately. However, the statistical data does not provide sufficient grounds to estimate separate prices or rates for loans and deposits. Loan revenues cannot be disentangled from those earned on other fixed-income investments, and deposit interest expenses cannot be isolated from interest which is paid on other liabilities. Consequently, the construction of the Lerner index rests on the estimation of price and marginal costs of a single indicator of total banking activity. Following the literature, total assets account for the aggregate product of the bank. Under the assumption that the heterogeneous flow of services produced by a bank is proportional to its total assets, $P_{T A}$ is calculated as the ratio of total revenues to total assets.

In order to derive $M C$, we estimate the following translog cost function for each country separately to reflect different technologies, while capturing bank specificities using bank fixed effects:

$$
\begin{aligned}
\ln C= & \beta_{0}+\beta_{1} \ln Q+\beta_{2} / 2 \ln Q^{2}+\sum_{k=1}^{2} \gamma_{k} \ln W_{k}+\sum_{k=1}^{2} \alpha_{k} \ln Z_{k}+ \\
& 1 / 2 \sum_{k=1}^{2} \sum_{j=1}^{2} \delta_{k j} \ln W_{k} \ln W_{j}+1 / 2 \sum_{k=1}^{2} \sum_{j=1}^{2} \gamma_{k j} \ln Z_{k} \ln Z_{j}+ \\
& 1 / 2 \sum_{k=1}^{2} \Phi_{k} \ln Q \ln W_{k}+1 / 2 \sum_{k=1}^{2} \eta_{k} \ln Q \ln Z_{k}+ \\
& 1 / 2 \sum_{k=1}^{2} \sum_{j=1}^{2} \omega_{k j} \ln W_{k} \ln Z_{j}+\xi_{1} T+1 / 2 \xi_{2} T^{2}+\xi_{3} \ln Q \\
& +\sum_{k=1}^{2} \lambda_{k} T \ln W_{k}+\sum_{k=1}^{2} \rho_{k} T \ln Z_{k}+\varepsilon
\end{aligned}
$$

where bank costs (Cost) are a function of output ( $Q$ for total assets), three input prices ( $W_{1}$ for the price of funds, $W_{2}$ for the price of physical capital, and $W_{3}$ for the price of labor), a vector of fixed net-puts ( $Z_{1}$ for fixed assets, $Z_{2}$ for total nominal value of off-balance sheet items, and $Z_{3}$ for equity capital), and technical change $T$ (Trend to capture movements in the cost function over time). Standard symmetry restrictions and input price homogeneity of degree one are required to estimate (2). Marginal $\operatorname{costs} M C_{T A}$ are then computed as:

$$
M C_{T A}=C / Q\left[\beta_{1}+\beta_{2} \ln Q+\sum_{k=1}^{2} \Phi_{k} \ln W_{k}+v_{3} T\right]
$$

Following Koetter et. al. (2008) we estimate efficiency-adjusted Lerner indices as:

$$
\left(A R_{T A .}-M C_{T A}\right) / A R_{T A}
$$


$A R$ denotes average revenues $(R E V / T A)$ and $R E V=T P-T C$. Total expected profits are derived from the profit function (Eq.(5)) discussed below and expected total costs are calculated using Eq. (2).

Cost and profit efficiency levels measure how well a bank is predicted to perform relative to other banks in a particular sample or a peer group for producing the same output bundle under the same exogenous conditions. Following the intermediation approach, banks are modeled as financial intermediaries that collect deposits and other liabilities and transfer them into interestearning assets such as loans and investments (Sealey and Lindley, 1977). Using parametric stochastic frontier analysis, cost and profit efficiency scores are estimated from the following equation:

$$
\ln A=f(\ln Q, \ln W)+\ln \varepsilon
$$

where $A$ is either total operating costs or total profits, and $Q$ and $W$ denote bank output and input prices defined above. The underlying functional form used is the translog specification of Eq. (2) where the dependent variable is either bank profits or operating costs. The error term $\varepsilon$ is decomposed into $\nu-u(\nu+u)$ for the profit (cost) model, where $\nu$ and $u$ are two components that are assumed to be multiplicatively separable from the rest of the function. While $\nu$ is a two-sided disturbance that accounts for uncontrollable (random) factors, $u$ is a one-sided non-negative inefficiency term. Using the maximum likelihood technique, Eq. (5) is estimated separately for each country with bank fixed effects to derive individual bank efficiency scores (Battese and Coelli, 1992). Following Berger and Mester (2003), alternative profit efficiency is preferred over the standard profit function because of the international dimension of the sample.

Bank stability

The Z-index assesses overall stability at the bank level (Boyd et al., 2006; Berger et al., 2009). This proxy of bank stability combines indicators of profitability, leverage, and return volatility into a single measure. It provides information on the number of standard deviation units by which profitability would have to decline before bank capitalization is depleted. It is given by the ratio:

$$
Z=(R O A+E / T A) / \sigma_{R O A}
$$

where $R O A$ and $E / T A$ are the average return on assets and equity to total assets, respectively, over the sample period, and $\sigma_{R O A}$ is the standard deviation of return on assets. The bank stability indicator increases with higher profitability and capitalization levels, and decreases with unstable earnings reflected by a higher standard deviation of return on assets. Stated differently, an increase (decrease) in the Z-index indicates a decrease (increase) in overall bank risk exposure and more (less) bank stability.

Since it is difficult to assess and capture bank stability using a single measure, the sensitivity of the results is also checked using risk-adjusted measures of return for each bank following Mercieca et al. (2007) as:

$$
R A_{R O A}=R O A / \sigma_{R O A} \text { and } R A_{R O E}=R O E / \sigma_{\mathbf{R O E}}
$$

where $R A_{R O A}$ and $R A_{R O E}$ denote risk-adjusted $R O A$ and $R O E$, respectively. Here again, higher values of risk-adjusted rates of return indicate more bank stability.

In order to investigate the effect of market power on bank efficiency and stability we run cross-section regressions of the following basic model:

$$
E F F=f(\text { MarketPower, } \text { PortfolioCharacteristics, Reg.Environment })
$$

where the dependent variable $E F F$ measures each of bank cost efficiency, alternative profit efficiency and stability, all of which are calculated at the bank level. Since bank cost and alternative profit efficiency scores are bound between zero and one, Tobit models are more appropriate because they are better fit models where the dependent variable is derived from a 
first-stage regression (Greene, 2005). The results of specification tests also confirm that a Tobit specification is preferred to a conventional treatment of efficiency scores.

In turn, the Z-index proxies bank stability, with larger values indicating more bank stability and less bank risk potential. As sensitivity checks, the two other risk-adjusted rates of returns indicators used are $R A_{R O A}$ and $R A_{R O E}$.

The main independent variable in (8) is the degree of market power measured by the Lerner index, or the mark-up of price over marginal costs, with higher values implying higher pricing power and less competitive market conditions. The Lerner index is the preferred measure of the degree of market power compared to other traditional indicators of market structure because it is observed at the bank level, similar to the unit of analysis of bank efficiency and stability to which they are related. The two different specifications of the Lerner index used include a conventional Lerner and an efficiency-adjusted Lerner. The latter adjusted Lerner measure derives from a structural model which, as explained in the previous section, better accounts for the inter-relatedness between market power and bank efficiency, thereby addressing endogeneity concerns.

Granger causality tests and variables

To investigate the direct effect of competition on efficiency, we analyze the nexus between the two alternative measures of profit efficiency and the Lerner index.

In a similar vein to Berger (1995), Berger and DeYoung (1997), and Williams (2004), we use Granger causality tests as follows

$$
y_{i t}=\alpha_{0}+\sum_{j=1}^{n} \alpha_{j} y_{i(t-1)}+\sum_{j=1}^{n} \beta_{j} x_{i(t-j)}+\gamma Z_{i t}+\eta_{t}+\varepsilon_{i t}
$$

and regress measures of profit efficiency on lags of both itself $\left(y_{t-1}, y_{t-2}\right)$, and on a Lerner index $\left(x_{t-1}, x_{t-2}\right)$ as a measure of competition; $Z_{i t}$ is a vector of control variables; $\boldsymbol{\eta}_{i}$ is a bank-specific effect and $\varepsilon_{i t}$ denotes the error term. We also run the regressions with the Lerner index as dependent variable and regress it on lags of both itself and lags of the measures of profit efficiency. For this analysis, we employ a panel data estimator with bank-fixed effects.

We use two annual lags in the baseline setup of our models. This lag structure avoids dropping a vast amount of information by using deeper lags. Granger causality analysis focuses on the $F$-Test for the joint significance of the two annual lags of $x$. If the two annual lags are significant, we can predict that $x$ Granger causes $y$, in the sense of changes in $x$ preceding changes in $y$. Granger causality however does not constitute causality in the economic sense. Similar to Berger (1995), we hone in on the sum of the lagged coefficients, because we are interested in the total effect of competition on profit efficiency over the sample period. To test whether the inferences from the basic setup are indeed causal in the Granger sense or merely spurious, we augment our regression specifications with a number of control variables.

Since we are predominantly interested in the effect of competition on efficiency, we choose control variables that are likely to affect efficiency. First, we include market share (log), total assets (log), asset growth, and squared asset growth into the Granger causality analysis. We expect that a bank's market share is positively related to profit efficiency because banks that are large relative to their relevant market can charge higher prices for their services (Berger and Mester, 1997). In contrast, profit efficiency of banks is frequently found to decrease in bank size, as larger banks have bigger difficulty in generating revenue efficiently (Stiroh, 2000; Berger and Mester, 1997). We also investigate the effect of asset growth. An expanding bank may not keep its efficiency under control and we therefore anticipate an inverse relation between asset growth and profit efficiency. We include a quadratic term to account for nonlinearities, since the effect of growth is likely to be different for aggressively growing institutions.

Second, we incorporate a Herfindahl-Hirschman index based on total assets to control for the degree of concentration in banking, and include a set of country dummies to soak up variation on the country level. Berger and Bonaccorsi di Patti (2006) show that efficiency is 
positively affected by concentration in banking markets because banks can increase net revenues by exerting market power, and Akhavein, Berger, and Humphrey (1997) find that mergers among large country-regionplaceU.S. banks enable the merged entity to improve profit efficiency, a finding that they assign to benefits from diversification. Since we compare Herfindahl indices across different markets, we also include the log of total banking system assets to control for the size of the different systems (Breshanan, 1989).

\section{EMPIRICAL RESULTS}

The 229 banks included in our sample are from Botswana, Kenya, Nigeria, S. Africa, Tanzania, Uganda and Zambia. Financial statement data for the banks were taken from Fitch-IBCA's BankScope dataset for the period 2009-2016. Table 6 (Appendix) gives a summary of the descriptive statistics of banking data for the seven African countries under investigation.

Table 1 presents the results of the country averages of the conventional Lerner index, the efficiency-adjusted Lerner index, cost efficiency, profit efficiency, the Z-index, and risk-adjusted rates of return over the period 2009-2016.

\begin{tabular}{|l|l|l|l|l|l|l|l|}
\hline Table 1. Country averages of different indices and efficiency scores \\
\hline Country & $\begin{array}{l}\text { Conventiona } \\
\text { Lerner }\end{array}$ & $\begin{array}{l}\text { Efficiency } \\
\text { Lerner }\end{array}$ & $\begin{array}{l}\text { Cost } \\
\text { Efficiency }\end{array}$ & $\begin{array}{l}\text { Profit Effi- } \\
\text { ciency }\end{array}$ & Z-index & $\begin{array}{l}\text { Risk- } \\
\text { Adjusted } \\
\text { ROA }\end{array}$ & $\begin{array}{l}\text { Risk- } \\
\text { Adjusted } \\
\text { ROE }\end{array}$ \\
\hline Botswana & 29.42 & 60.39 & 75.37 & 33.59 & 36.24 & 2.96 & 2.72 \\
\hline Kenya & 37.04 & 54.57 & 71.28 & 30.17 & 30.11 & 3.04 & 3.39 \\
\hline Nigeria & 33.08 & 57.23 & 73.14 & 27.71 & 28.53 & 3.46 & 3.12 \\
\hline S. Africa & 29.15 & 63.38 & 76.32 & 35.04 & 38.32 & 3.67 & 3.82 \\
\hline Tanzani & 34.28 & 61.14 & 72.74 & 32.28 & 32.35 & 1.26 & 1.45 \\
\hline Uganda & 35.49 & 58.09 & 70.07 & 29.45 & 31.66 & 1.59 & 1.67 \\
\hline Zambi & 35.26 & 56.22 & 71.65 & 28.87 & 29.40 & 1.78 & 1.42 \\
\hline
\end{tabular}

The conventional Lerner figures show varying degrees of market power across countries, but the figures are generally closely aligned across all regions (around 35\% price mark-up over marginal costs) with the lowest estimate reported for S. Africa and placecountry-regionBotswana at $29 \%$. The estimated efficiency Lerner indices also vary across countries ranging from $55 \%$ to $63 \%$. In line of the findings of Koetter et al. (2008) for US banks, the magnitude of the efficiency-adjusted Lerner generally exceeds that of the conventional index.

The measure of bank cost (profit) efficiency is the actual level of costs (profits) relative to an efficient cost (profit) frontier. The efficiency estimation results appearing in Table 1 are in line with those reported in the literature, with higher scores indicating better efficiency levels (see Berger and Humphrey, 1997). While cost efficiency levels are closely aligned across countries, profit efficiency levels exhibit greater disparity (ranging from 27.7 to 35). It should be noted, however, that cross-country efficiency comparisons are to be treated with caution. It would be wrong to conclude that banks in S. Africa and country-regionBotswana are more profit efficient than banks in placecountry-regionNigeria. The reported efficiency averages per country or per region can only serve as reference, since a different frontier is estimated for each country.

Table 2 reports the results of the different estimations of Eq. (8) using bank cost and alternative profit efficiency as dependent variables, and Table 3 considers the Z-index and $R A_{R O A}$ measures of bank stability as exogenous variables. Each table includes the two different specifications of the Lerner index: a conventional Lerner and an efficiency-adjusted Lerner.

Following Berger et al. (2009), we include a quadratic term for the Lerner index to allow for a non-linear relationship between competition and each of bank efficiency and stability. In order to establish the sign of the relationship between the independent variable (Lerner index) and each of the dependent variables, the inflection point is calculated for every specification by setting the first-order derivative to zero and comparing its value to the empirical distribution of the Lerner index data. To illustrate, the inflection point of Model metricconverterProductID1 in1 in Table 
2 is -4.42 and the sign of the quadratic coefficient in Model 1 is negative, the resulting estimated function is a downward oriented or reverse parabola that decreases above the inflection point. Therefore, the empirical estimation supports a negative association between a bank's degree of market power and its level of cost efficiency. A similar analysis for each estimated model reports the sign of the relationship between variables of interest.

\begin{tabular}{|c|c|c|c|c|}
\hline \multicolumn{5}{|c|}{ Table 2. Market power and bank efficiency } \\
\hline & \multicolumn{2}{|c|}{ Dependent variable: cost efficiency } & \multicolumn{2}{|c|}{ Dependent variable: profit efficiency } \\
\hline & conventional Lerner & Efficiency-adjusted Lerner & conventional Lerner & Efficiency-adjusted Lerner \\
\hline \multirow[t]{2}{*}{ Lerner index } & -0.0416 & -0.0638 & 0.2836 & 0.0562 \\
\hline & $(0.0174)$ & $(0.0132)$ & $(0.0434)$ & $(0.0157$ \\
\hline \multirow{2}{*}{ Lerner index-squared } & -0.00186 & -0.0361 & 0.0445 & 0.0614 \\
\hline & $(0.0037)$ & $(0.0228)$ & $(0.0389)$ & $(0.0402)$ \\
\hline \multirow[t]{2}{*}{ Loans-to-Assets } & 0.0239 & 0.0346 & -0.0507 & -0.0761 \\
\hline & $(0.0108)$ & $(0.0095)$ & $(0.0352)$ & $(0.0236)$ \\
\hline \multirow[t]{2}{*}{$\ln$ (Total Assets) } & 0.022 & 0.037 & -0.027 & -0.061 \\
\hline & $(0.0046)$ & $(0.0032)$ & $(0.0082)$ & $(0.0147)$ \\
\hline \multirow[t]{2}{*}{ Foreign Ownership } & -0.031 & -0.014 & 0.0232 & 0.0265 \\
\hline & $(0.0055)$ & $(0.0026)$ & $(0.0044)$ & $(0.0203)$ \\
\hline \multirow[t]{2}{*}{$\ln (\mathrm{GDP} \mathrm{pc})$} & -0.0418 & -0.0067 & -0.036 & -0.0211 \\
\hline & $(0.0051)$ & $(0.0032)$ & $(0.0057)$ & $(0.0092)$ \\
\hline Inflection point & -4.42 & -2.69 & 4.08 & 2.57 \\
\hline Sign of relationship & - & - & + & + \\
\hline Marginal effects & -0.0245 & -0.0314 & 0.0446 & 0.0619 \\
\hline \multicolumn{5}{|c|}{ Standard errors in parentheses. Bold figures indicate $\mathrm{p}<0.05$ or $\mathrm{p}<0.01$. } \\
\hline
\end{tabular}

The significant negative relationship between a bank's degree of market power and cost efficiency holds across both Lerner specifications. This suggests that banks with more market power operating in African developing countries are not able to reduce costs and achieve lower cost efficiency levels compared to their peers. Hughes et al. (2003) argue that management may signal market power by maintaining large offices and other excessive spending, possibly driving significant cost efficiency losses. However, except for Delis and Tsionas (2009) who report similar negative association between market power and efficiency for a sample of EU and US banks, the results do not agree with those reported for developed countries (Maudos and De Guevara (2007)).

Table 2 also shows the implications of the degree of market power (using the two different Lerner specifications) on bank alternative profit efficiency. The corresponding inflection point for Model 1 is estimated at 4.08, and the sign of the quadratic term is positive, pointing to a direct association between market power and alternative profit efficiency. This significant positive relationship holds for both models of alternative specifications of the Lerner index. These findings provide evidence against the notion that banks enjoying higher levels of market power achieve greater levels of profit efficiency, thus contradicting the "quiet life" hypothesis. They are opposite to those reported by Schaeck and Cihak (2008) who establish a positive effect of competition on alternative profit efficiency for EU and placecountry-regionUS banking.

Table 3 shows the results of the implication of market power on bank stability, using the Z-index and risk-adjusted return on assets as proxies of overall bank stability. The inflection point for Model 1 of Table 3 using the Z-index and the conventional Lerner specification is -2.94 and since the sign of the quadratic term is negative, the estimated function is a downward parabola that rises after the inflection point, implying a direct relationship between the degree of market power and the Z-index. The results suggest there is a significant and negative relationship between a bank's degree of market power and its level of stability across both Lerner specifications. This suggests that banks with a larger degree of market power are associated 
with lower levels of overall bank stability and increased risk potential. The findings for African countries thus contradict the traditional view on the trade-off between bank competition and stability, and are in line with those reported by De Nicoló et al. (2004), Boyd et al. (2006), Schaeck et al. (2009).

\begin{tabular}{|c|c|c|c|c|}
\hline \multicolumn{5}{|c|}{ Table 3. Market power and bank stability } \\
\hline & \multicolumn{2}{|c|}{ Dependent variable: $Z$-index } & \multicolumn{2}{|c|}{ Dependent variable: Risk-adjusted ROA } \\
\hline & conventional Lerner & Efficiency-adjusted Lerner & conventional Lerner & Efficiency-adjusted Lerner \\
\hline \multirow{2}{*}{ Lerner index } & -0.0352 & -0.0419 & 0.0331 & 0.0628 \\
\hline & $(0.0206)$ & $(0.0064)$ & $(0.0305)$ & $(0.0219)$ \\
\hline \multirow[t]{2}{*}{ Lerner index-squared } & -0.044 & -0.0395 & 0.0274 & 0.0537 \\
\hline & $(0.0052)$ & $(0.0381)$ & $(0.0216)$ & $(0.0048)$ \\
\hline \multirow[t]{2}{*}{ Loans-to-Assets } & 0.0327 & 0.0445 & -0.0408 & -0.0562 \\
\hline & $(0.0288)$ & $(0.037)$ & $(0.0326)$ & $(0.047)$ \\
\hline \multirow[t]{2}{*}{$\ln$ (Total Assets) } & 0.025 & 0.061 & -0.052 & -0.017 \\
\hline & $(0.0066)$ & $(0.0023)$ & $(0.0034)$ & $(0.0065)$ \\
\hline \multirow[t]{2}{*}{ Foreign Ownership } & -0.072 & -0.015 & 0.0311 & 0.0336 \\
\hline & $(0.016)$ & $(0.0028)$ & $(0.0084)$ & $(0.0107)$ \\
\hline \multirow[t]{2}{*}{$\ln (\mathrm{GDP} \mathrm{pc})$} & -0.034 & -0.075 & -0.0398 & -0.0309 \\
\hline & $(0.0061)$ & $(0.0037)$ & $(0.0192)$ & $(0.0355)$ \\
\hline Inflection point & -2.94 & -2.03 & 4.56 & 2.75 \\
\hline Sign of relationship & - & - & + & + \\
\hline Marginal effects & -0.0209 & -0.0354 & 0.0277 & 0.0286 \\
\hline \multicolumn{5}{|c|}{ Standard errors in parentheses. Bold figures indicate $\mathrm{p}<0.05$ or $\mathrm{p}<0.0$} \\
\hline
\end{tabular}

In order to check the sensitivity of the Z-index results to other indicators of bank stability, Table 3 also shows the implications of market power on risk-adjusted $R O A$. According to these results, a positive sign is consistently reported between different measures of market power and risk-adjusted $R O A$. This indicates that a higher degree of market power is significantly positively associated with larger risk-adjusted rates of return. Thus, the sensitivity checks using proxies other than the Z-index support the positive association between market power and bank stability. As markets become more concentrated, African banks are likely to exhibit lower variability of returns.

To sum, the empirical analysis for African countries shows that a higher degree of market power results in profit efficiency gains and enhanced bank stability, despite significant cost efficiency losses. Banks with higher loans to assets ratios exhibit significantly higher Z-indices, suggesting that firms that have a higher credit risk exposure (higher loans to assets ratios) are in fact exposed to a lower level of overall bank risk.

Furthermore, we run Granger causality tests to examine the nexus between competition and efficiency. The findings reported in Table 4 show that the sum of the lagged coefficients for the Lerner index is positive and significant at the one percent level. This positive relationship between the Lerner index and alternative profit efficiency suggests that market power increases alternative profit efficiency, result that is in line with our findings reported in Table 2. In column 2 , the sum of the coefficients of the alternative profit efficiency variable is positive and significant, indicating that progress in terms of alternative profit efficiency increases market power. Thus, efficiency Granger-causes market power indicating, that changes in profit efficiency precede changes in market power. The sum of the lagged Lerner indices is positive and significant, indicating positive conditional correlation.

Market share is also positively associated with profit efficiency. This positive effect could reflect that banks that are large relative to the system have better access to production technologies so that they can increase profit efficiency more easily than smaller banks. In contrast, bank size in terms of total assets is inversely related to the dependent variable in column 1 , 
suggesting that large institutions tend to benefit less from efficiency increases than smaller banks.

\begin{tabular}{|c|c|c|c|c|c|c|c|c|}
\hline Dependent & Alternat & Conventiona & Alternat & Efficiency & Cost & Conventional & Cost & Efficiency \\
\hline Variable & $\begin{array}{l}\text { Profit Effi- } \\
\text { ciency }\end{array}$ & Lerner & $\begin{array}{l}\text { Profit Effi- } \\
\text { ciency }\end{array}$ & $\begin{array}{l}\text { Adjusted } \\
\text { Lerner }\end{array}$ & Efficiency & Lerner & Efficiency & $\begin{array}{l}\text { Adjusted } \\
\text { Lerner }\end{array}$ \\
\hline Alternative & $-0,2503$ & 0,038 & $-0,3162$ & $-0,0014$ & - & - & - & - \\
\hline $\begin{array}{l}\text { Profit effic } \\
(\mathrm{t}-1)\end{array}$ & $(0,026)$ & 0,0014 & 0,0456 & 0,0033 & & & & \\
\hline Alternative & $-0,3411$ & 0,0049 & $-0,3809$ & $-0,054$ & - & - & - & - \\
\hline $\begin{array}{l}\text { Profit effic } \\
(\mathrm{t}-2)\end{array}$ & $(0,051)$ & 0,007 & 0,0485 & 0,0076 & & & & \\
\hline Total & $-0,5914$ & 0,0429 & $-0,6971$ & $-0,0554$ & - & - & - & - \\
\hline F-statistic & 8,02 & 7,47 & 8,76 & 7,25 & & & & \\
\hline \multirow{2}{*}{$\begin{array}{l}\text { Lerner (t- } \\
1)\end{array}$} & 0,382 & 0,475 & 0,3197 & 0,2642 & 0,0025 & 0,4261 & 0,0165 & 0,4719 \\
\hline & $(0,207)$ & $(0,0466)$ & $(0,1007)$ & $(0,0465)$ & $(0,0012)$ & $(0,0387)$ & $(0,0056)$ & $(0,0255)$ \\
\hline \multirow{2}{*}{$\begin{array}{l}\text { Lerner (t- } \\
2)\end{array}$} & $-0,2098$ & $-0,034$ & $-2,3578$ & $-0,0419$ & $-0,0567$ & $-0,2696$ & $-0,0361$ & $-0,2432$ \\
\hline & $(0,1075)$ & $(0,0015)$ & $(0,3455)$ & $(0,0123)$ & $(0,0224)$ & $(0,0517)$ & $(0,0409)$ & $(0,0617)$ \\
\hline $\begin{array}{l}\text { Lerner to- } \\
\text { tal }\end{array}$ & 0,1722 & 0,441 & $-2,0381$ & 0,2043 & $-0,0542$ & 0,1565 & $-0,0196$ & 0,2287 \\
\hline F-statistic & 45,11 & 74,29 & 38,14 & 56,39 & 17,22 & 24,46 & 38,67 & 47,05 \\
\hline $\begin{array}{l}\text { Market } \\
\text { share }\end{array}$ & 0,0265 & $-0,0178$ & $-0,2419$ & 0,0452 & $-0,0166$ & $-0,047$ & $-0,0266$ & 0,0388 \\
\hline$(\log )$ & $(0,0107)$ & $(0,0034)$ & $(0,0335)$ & $(0,0124)$ & $(0,0024)$ & $(0,012)$ & $(0,0047)$ & $(0,0167)$ \\
\hline $\begin{array}{l}\text { Total } \\
\text { assets }\end{array}$ & $-0,2109$ & 0,0641 & - & - & $-0,025$ & 0,0426 & - & - \\
\hline$(\log )$ & $(0,0175)$ & $(0,043)$ & & & 0,008 & 0,0022 & & \\
\hline \multirow{2}{*}{$\begin{array}{l}\text { Asset } \\
\text { growth }\end{array}$} & - & - & 0,0619 & 0,0285 & - & - & $-0,0372$ & $-0,0773$ \\
\hline & & & $(0,0208)$ & $(0,0031)$ & & & $(0,0056)$ & $(0,0216)$ \\
\hline $\begin{array}{l}\text { Asset } \\
\text { growth }\end{array}$ & - & - & $-0,0244$ & $-0,0409$ & - & - & 0,0014 & 0,0022 \\
\hline (squared) & & & $(0,0205)$ & $(0,0011)$ & & & $(0,0007)$ & $(0,008)$ \\
\hline \multirow[t]{2}{*}{$\mathrm{H}-\mathrm{H}$ Index } & - & - & $-0,4427$ & $-0,0326$ & - & - & $-0,0027$ & 0,0074 \\
\hline & & & $(0,0319)$ & $(0,0019)$ & & & $(0,0076)$ & $(0,0012)$ \\
\hline $\begin{array}{l}\text { Cost } \\
\text { efficiency }\end{array}$ & - & - & - & - & $-0,2655$ & $-0,3719$ & $-0,4916$ & $-0,3872$ \\
\hline$(\mathrm{t}-1)$ & & & & & $(0,0307)$ & $(0,2144)$ & $(0,0328)$ & $(0,0445)$ \\
\hline $\begin{array}{l}\text { Cost } \\
\text { effi ciency }\end{array}$ & - & - & - & - & $-0,4085$ & $-0,4189$ & $-0,2366$ & $-0,3922$ \\
\hline$(\mathrm{t}-2)$ & & & & & $(0,101)$ & $(0,2066)$ & $(0,0578)$ & $(0,0551)$ \\
\hline Total & - & - & - & - & $-0,674$ & $-0,7908$ & $-0,7282$ & $-0,7794$ \\
\hline F-statistic & & & & & 46,09 & 7,32 & 69,47 & 4,26 \\
\hline $\mathrm{R}$-squared & 0,2156 & 0,3211 & 0,2609 & 0,3827 & 0,2451 & 0,3795 & 0,2027 & 0,3728 \\
\hline \multicolumn{9}{|c|}{$\begin{array}{l}\text { Notes: Standard errors in parentheses. Bold figures indicate } \mathrm{p}<0.05 \text { or } \mathrm{p}<0.01 \text {. We regress measures } \\
\text { of profit efficiency on lags of both itself }(\mathrm{t}-1, \mathrm{t}-2) \text {, and on a Lerner index as a measure of competition. } \\
\text { We also run the regressions with the Lerner index as dependent variable and regress it on lags of both } \\
\text { itself and lags of the measures of profit efficiency. }\end{array}$} \\
\hline
\end{tabular}


To further explore the result in column 1 that market power impedes alternative profit efficiency, we add additional control variables that may also influence efficiency. In columns 3 and 4 , we include asset growth, asset growth squared and the $\mathrm{H}-\mathrm{H}$ index.

The findings in columns 3 and 4 also illustrate significant effects of asset growth on alternative profit efficiency. The $\mathrm{H}-\mathrm{H}$ index shows a negative and significant sign in column 3, suggesting that banks operating in more concentrated and larger markets are less profit efficient. Columns $5-8$ use the concept of cost efficiency. These findings, in general, confirm the results reported in the preceding columns.

To investigate the sensitivity of our results with respect to the measurement of efficiency, we run Granger causality tests in Table 5 with efficiency scores based on the concept of standard profit efficiency. Standard profit efficiency scores are calculated using stochastic frontier techniques but bank output quantities are allowed to vary. Therefore, in the estimation of the structural model of Eq. (5) output prices are replaced with output quantities (input prices remain unaffected in relation to the estimation of alternative profit efficiency scores). This model measures how close a bank is to the efficiency frontier given its output prices (standard prices, standard profits), whereas the alternative profit efficiency scores measure how close a bank is to the efficiency frontier given its output levels (Schaeck and Cihak, 2008).

The findings with the standard profit efficiency measure provide more evidence contradicting the 'Competition-Efficiency'-Hypothesis. While the sum of the lagged coefficients of the Lerner index still shows a positive sign implying that market power increases profit efficiency, the F-Statistic is not significant.

In sum, our findings seem to suggest that profit efficiency Granger causes market power. Our results indicate that banks that are able to operate more profit efficiently will gain greater market power in comparison with their peers.

\begin{tabular}{|c|c|c|c|c|}
\hline \multicolumn{5}{|c|}{ Table 5. Robustness analysis for Granger causality test } \\
\hline Dependent & Standard & Conventional & Standard & Efficiency \\
\hline Variable & Profit Efficiency & Lerner & Profit Efficiency & Adjusted Lerner \\
\hline Standard & $-0,3816$ & 0,0148 & $-0,4162$ & $-0,0278$ \\
\hline Profit effic (t-1) & $(0,0112)$ & $(0,0271)$ & $(0,0307)$ & $(0,0194)$ \\
\hline Standard & $-0,4872$ & 0,0266 & $-0,3177$ & $-0,0115$ \\
\hline Profit effic $(\mathrm{t}-2)$ & $(0,0294)$ & $(0,0028)$ & $(0,0152)$ & $(0,0389)$ \\
\hline Total & $-0,8688$ & 0,0414 & $-0,7339$ & $-0,0393$ \\
\hline F-statistic & 46,14 & 5,58 & 32,76 & 2,07 \\
\hline \multirow[t]{2}{*}{ Lerner $(\mathrm{t}-1)$} & 3,0241 & 0,3475 & 4,5211 & 0,4916 \\
\hline & $(1,2566)$ & $(0,1082)$ & $(2,1327)$ & $(0,1752)$ \\
\hline \multirow[t]{2}{*}{ Lerner (t-2) } & $-0,8362$ & $-0,1725$ & $-4,7928$ & $-0,0529$ \\
\hline & $(0,1945)$ & $(0,0288)$ & $(3,0655)$ & $(0,0352)$ \\
\hline Lerner total & 2,1879 & 0,175 & $-0,2717$ & 0,4387 \\
\hline F-statistic & 0,62 & 12,37 & 7,96 & 62,14 \\
\hline Market share & 0,0465 & $-0,0277$ & 0,0451 & 0,0587 \\
\hline$(\log )$ & $(0,0223)$ & $(0,0612)$ & $(0,0156)$ & $(0,0219)$ \\
\hline Total assets & 2,1932 & 0,1688 & 3,4211 & 0,0367 \\
\hline$(\log )$ & $(0,1457)$ & $(0,0591)$ & $(0,0378)$ & $(0,0188)$ \\
\hline \multirow[t]{2}{*}{ Asset growth } & - & - & $-0,2285$ & 0,0249 \\
\hline & & & $(0,0417)$ & $(0,0711)$ \\
\hline Asset growth & - & - & 0,1786 & 0,0399 \\
\hline (squared) & & & $(0,0368)$ & $(0,0247)$ \\
\hline \multirow[t]{2}{*}{ H-H Index } & - & - & $-1,7514$ & $-0,0677$ \\
\hline & & & $(1,0611)$ & $(0,0209)$ \\
\hline R-squared & 0,2718 & 0,3089 & 0,2061 & 0,2642 \\
\hline
\end{tabular}




\section{CONCLUSION}

Most emerging countries have recently embraced financial liberalization as a means to achieve higher rates of economic growth. With the globalization of financial services worldwide, the bank model is shifting toward a universal banking system to provide a wide array of financial services (including commercial activities, investment banking and insurance underwriting) under the umbrella of the same financial conglomerate. As competitive conditions tighten and banks seek to increase their degree of market power, policymakers are concerned with the overall implications of changing banking structures, especially in light of the adverse implications of the late global financial turmoil onto developing countries.

The relationship between competition policies and financial stability is poorly documented for developing countries and no consensus prevails in the literature on the implications of market power on bank stability. This paper examines the impact of a higher degree of market power on each of bank efficiency and stability.

Overall, our empirical analysis for African countries shows that a higher degree of market power results in profit efficiency gains and enhanced bank stability, despite significant cost efficiency losses. Banks with higher loans to assets ratios exhibit significantly higher Z-indices, suggesting that firms that have a higher credit risk exposure (higher loans to assets ratios) are in fact exposed to a lower level of overall bank risk.

In developing countries, banks that command a high price mark-up over marginal costs may be reasonably adept at improving their profit efficiency, but they do not do so well in terms of cost efficiency levels. As geographical and regulatory borders recede and the use of information technology intensifies, the global dimension of banking may evolve to create new opportunities for bank managers who ensure a wider spectrum of returns, while possibly passing on the resulting excessive costs to their clients.

Further, as banks gain market power, they also benefit from greater firm stability and reduced risk potential. This result supports the traditional view that increased competition may undermine bank stability. It can also provide a rationale for the intense merger activity that has taken place over the last two decades in the context of developed countries. More importantly, the finding may be relevant for policymakers in developing countries where the banking system is strained.

Our results also seem to suggest that efficiency Granger-causes market power indicating, that changes in profit efficiency precede changes in market power. Banks that are able to operate more profit efficiently will gain greater market power in comparison with their peers.

The global dimension of the recent financial crisis has demonstrated that no country is immune to the turmoil hitting financial markets in developed countries. While antitrust laws in the US ensure that banking markets remain competitive (Berger et al., 2009) and competition policy is taken seriously in the EU (Carletti and Vives, 2008), the results suggest that increased market power in stressed banking systems of developing countries may in fact be welcome due to the likely increase in bank soundness. Further research on the issues of competition, bank efficiency and market stability may be undertaken using banking data from developing countries in Latin America and South East Asia.

\section{REFERENCES}

[1] Akhavein, J., A. N. Berger, and D. B. Humphrey (1997), "The effects of megamergers on efficiency and prices: Evidence from a bank profit function". Review of Industrial Organization, Vol. 12, pp. 95-139.

[2] Barth, J., G. Caprio, and R. Levine (2004), "Bank regulation and supervision: What works best?", Journal of Financial Intermediation, Vol. 13, pp. 205-248.

[3] Beck, T., A. Demirgüç-Kunt, and R. Levine (2006), "Bank concentration, competition, and crises: First results". Journal of Banking and Finance, Vol. 30, pp. 1581-1603.

[4] Berger, A. N. (1995), "The relationship between capital and earnings in banking". Journal of Money, Credit, and Banking, Vol. 27, pp. 432-456.

[5] Berger, A. N., and T. H. Hannan (1998), "The efficiency cost of market power in the banking industry: A test of the "quiet life" and related hypotheses", Review of Economics and Statistics, Vol. 80, pp. 454-465. 
[6] Berger, A. N., and E. Bonaccorsi di Patti (2006), "Capital structure and firm performance: A new approach to testing agency theory and an application to the banking industry", Journal of Banking and Finance, Vol. 30, pp. 1065-1102.

[7] Berger, A. N., and L. Mester (1997), "Inside the black box: What explains differences in the efficiencies of financial institutions?", Journal of Banking and Finance, Vol. 21, pp. 895- 947.

[8] Berger, A. N., and R. De Young (1997), "Problem loans and cost efficiency in commercial banks.", Journal of Banking and Finance, Vol. 21, pp. 849-870.

[9] Berger, A. N., A. Demirgüç-Kunt, R. Levine and J. G. Haubrich (2004), "Bank concentration and competition: An evolution in the making", Journal of Money, Credit and Banking, Vol. 36 (3), pp. 434-450.

[10] Besanko, D., and A. V. Thakor (1993), "Relationship banking, deposit insurance and bank portfolio choices". In: Vives, X., and C. Mayer (eds.) Capital markets and financial intermediation, Cambridge: University Press, pp. 292-318.

[11] Boone, J. (2001), "Intensity of competition and the incentive to innovate", International Journal of Industrial Organization, Vol. 19, pp. 705-726.

[12] Boot, A. and S. Greenbaum (1993) Bank regulation, reputation and rents: Theory and policy implications. In: Mayer, Colin and Xavier Vives (eds.) Capital markets and financial intermediation. Cambridge: University Press, pp. 262-285.

[13] Boyd, J. H., and G. de Nicoló (2005), "The theory of bank risk-taking and competition revisited.", Journal of Finance, Vol. 60, pp. 1329-1342.

[14] Boyd, J. H., and D. Runkle (1993), "Size and performance of banking firms", Journal of Monetary Economics, Vol. 31, pp. 47-67.

[15] Bresnahan, T.F. (1989) Empirical studies of industries with market power. in R.L. Schmalensee and R.D. Willig (eds.) Handbook of Industrial Organization, Vol. 2., Amsterdam: Elsevier Science.

[16] Carletti, E., P. Hartmann, and G. Spangnolo (2007), "Bank mergers, competition, and liquidity",. Journal of Money, Credit and Banking, Vol. 39, No. 5 (August 2007), pp. 1067-1105.

[17] Carletti, E. and P. Hartmann (2003) Competition and stability: What's special about banking? In Mizen, P. D. (ed.) Monetary History, Exchanges Rates and Financial Markets: Essays in Honour of Charles Goodhart, Vol. 2, Cheltenham: Edward Elgar, pp. 202-229.

[18] Casu, B., and G. Girardone (2007) Does competition lead to efficiency? The case of EU commercial banks. Essex University, Discussion Paper No. 07-01.

[19] Casu, B., and G. Girardone (2006), Bank competition, concentration, and efficiency in the single European market. The Manchester School, Vol. 74, pp. 441-468.

[20] Chan, Y., S. I. Greenbaum, and A. V. Thakor (1986), "Information reusability, competition and bank asset quality", Journal of Banking and Finance, Vol. 10, pp. 255-276.

[21] Chen, X. (2007), "Banking deregulation and credit risk: Evidence from the EU" Journal of Financial Stability, Vol. 2, pp. 356-390.

[22] Cihák, Martin (2007), "Systemic loss: A measure of financial stability". Czech Journal of Economics and Finance, Vol. 57, pp. 5-26.

[23] Cihák, M. and H. Hesse (2008) Islamic banks and financial stability: An empirical analysis. IMF Working Paper, WP/08/16, Washington, D.C.: International Monetary Fund.

[24] Claessens, S., and L. Laeven (2004), "What drives bank competition? Some international evidence". Journal of Money, Credit, and Banking, Vol. 36, pp. 563-583.

[25] Dell'Ariccia, G., and R. Marquez (2006), "Lending booms and lending standards". Journal of Finance, Vol. 61 , pp. 2511-2546.

[26] Demirgüç-Kunt, A. and E. Detragiache (1998), "The determinants of banking crises in developing and developed countries". IMF Staff Papers, Vol. 45, pp. 81-109, Washington, D. C: International Monetary Fund.

[27] Demirgüç-Kunt A, Detragiache E, and T. Tressel (2006), "Banking on the principles: Compliance with Basel core principles and bank soundness". IMF Working Paper WP/06/242, Washington, D.C.: International Monetary Fund.

[28] Demsetz, H. (1973), "Industry structure, market rivalry, and public policy". Journal of Law and Economics, Vol. 16, pp. 1-9.

[29] DeYoung, R., I. Hasan, and B. Kirchhoff (1998), "The impact of out-of-state entry on the cost efficiency of local commercial banks", Journal of Economics and Business, Vol. 50, pp. 191-203.

[30] DeYoung, R. (1998), "Management quality and x-inefficiency in national banks". Journal of Financial Services Research, Vol., 13 pp. 5-22.

[31] Diamond, D. (1984), "Financial intermediation and delegated monitoring". Review of Economic Studies, Vol. 51, pp. 393-414.

[32] Hauswald, R., and R. Marquez (2006), "Competition and strategic information acquisition in credit markets". Review of Financial Studies, Vol. 19, pp. 967-1000.

[33] Hay and Liu (1997), "The Efficiency of Firms: what Difference does Competition Make?", Economic Journal, Vol. 107, pp. 597-617. 
[34] Hellmann, T., K. Murdock, and J. Stiglitz (2000), "Liberalization, moral hazard in banking, and prudential regulation: are capial requirements enough?", American Economic Review, Vol. 90, pp. 147-165.

[35] Humphrey, D., and L. Pulley (1997), "Bank's responses to deregulation: Profits, technology and efficiency". Journal of Money, Credit and Banking, Vol. 29, pp. 73-93.

[36] Keeley, M. C. (1990), "Deposit insurance, risk and market power in banking",. American Economic Review, Vol. 80, pp. 1183-1200.37.

[37] Koetter, M., J. Kolari, and L. Spierdijk (2008) Testing the 'quiet life' of U.S. banks with adjusted Lerner indices. Paper presented at the 44th Bank market structure conference, Federal Reserve Bank of Chicago. May 14th 2008.

[38] Koetter, M., and D. Porath (2007) Efficient, profitable and safe banking: an oxymoron? Evidence from a panel VAR approach. Deutsche Bundesbank Discussion Paper Series 2: Banking and Financial Studies No $02 / 2007$.

[39] Koskela, E., and R. Stenbacka (2000), "Is there a tradeoff between bank competition and financial fragility?", Journal of Banking and Finance, Vol. 24, pp. 1853-1873.

[40] Kumbhakar, S. C, A. Lozano-Vivas, C. A. Lovell, and I. Hasan (2001), "The Effects of deregulation on the performance of financial institutions: The case of Spanish savings banks". Journal of Money, Credit and Banking, Vol. 33, pp. 101-20.

[41] Kwan, S., and Eisenbeis, RA. (1997), "Bank risk, capitalization, and operating efficiency". Journal of Financial Services Research, Vol. 12, pp. 117-131.

[42] Mercieca, S., K. Schaeck, and S. Wolfe (2007), "Small banks in Europe: Benefits from diversification?", Journal of Banking and Finance, Vol. 31, pp. 1975-98.

[43] Mishkin, F. S. (1999), "Financial consolidation: Dangers and opportunities". Journal of Banking and Finance, Vol. 23, pp. 675-691.

[44] Padoa-Schioppa, T. (2001), "Competition and supervision in the banking industry: A changing paradigm?", European Finance Review, Vol. 5, pp. 1-5.

[45] Pagano, M. (1993), "Financial markets and growth: An overview". European Economic Review, Vol. 37, pp. 613-622.

[46] Petersen, M., and R. Rajan (1995), "The effect of credit market competition on lending relationships". The Quarterly Journal of Economics, Vol. 110, pp. 407-43.

[47] Schaeck, K., M. Cihák, and S. Wolfe (2006), "Are more competitive banking systems more stable?" IMF Working Paper, WP/06/143, Washington, D.C.: International Monetary Fund.

[48] Schaeck, K., M. Cihák (2007), Banking competition and capital ratios. IMF Working Paper, WP/07/216, Washington, D.C.: International Monetary Fund.

[49] Stiroh, K. (2004), "Diversification in Banking: Is noninterest income the answer?" Journal of Money, Credit, and Banking, Vol. 36, pp. 853-882.

[50] Stiroh, K. (2000), "How did bank holding companies prosper in the 1990s?" Journal of Banking and Finance, Vol. 24, pp. 1703-1745.

[51] Stiroh, K., and A. Rumble (2006), "The dark side of diversification: The case of US financial holding companies". Journal of Banking and Finance, Volume 30, pp. 2131-2161.

[52] Tirole, J. (1998) Theory of industrial organization. Cambridge: MIT Press.

[53] Vander Vennet, R. (2002), "Cost and profit efficiency of financial conglomerates and universal banks in Europe". Journal of Money, Credit, and Banking, Vol. 34, pp. 254-282.

[54] Wheelock, D. C., and P. W. Wilson (1995), "Explaining bank failures: Deposit insurance, regulation, and efficiency" Review of Economics and Statistics, Vol. 77, pp. 689-700.

[55] Williams, J. (2004), "Determining management behaviour in European banking". Journal of Banking and Finance, Vol. 28, pp. 2427-2460. 


\section{APPENDIX}

\begin{tabular}{|l|l|l|l|l|l|}
\hline Table 6. Descriptive statistics & Mean (\$) & $\begin{array}{l}\text { Standard } \\
\text { Deviation }\end{array}$ & Variable & Mean & $\begin{array}{l}\text { Standard } \\
\text { Deviation }\end{array}$ \\
\hline Variable & 281433792 & 204653771 & Total assets (log) & 7.42 & 2.81 \\
\hline Deposits & 0.017 & Market share (log) & -4.32 & 1.47 \\
\hline $\begin{array}{l}\text { Interest expenses/ Total de- } \\
\text { posits }\end{array}$ & 0.044 & & 0.03 & 0.002 \\
\hline $\begin{array}{l}\text { Capital and personnel Ex- } \\
\text { penses/ Total assets }\end{array}$ & 0.058 & 0.011 & Asset growth & 0.09 & 21.52 \\
\hline Total operating income & 548312 & 109654 & H-H index & 35356007 & 12289745 \\
\hline Total assets & 144467310 & 674338412 & Z-score & Equity capital & 0.02 \\
\hline Fixed assets/ Total assets & 0.18 & 0.05 & Alternative profit efficiency & 0.78 & 0.32 \\
\hline $\begin{array}{l}\text { Loan loss provisions/ Equity } \\
\text { capital }\end{array}$ & 0.12 & 0.06 & & Standard profit efficiency & 0.65 \\
\hline $\begin{array}{l}\text { Total cost/ Total assets } \\
\text { Loans/ Total assets }\end{array}$ & 0.13 & 0.09 & 0.17 & Cost efficiency & 0.70 \\
\hline $\begin{array}{l}\text { Note: Figures computed from bank statement data of 229 banks from Botswana, Kenya, Nigeria, S. } \\
\text { Africa, Tanzania, Uganda and Zambia for the period 2009-2016. }\end{array}$ & 0.33 \\
\hline
\end{tabular}

